Izvorni znanstveni rad DOI: $10.17234 /$ Croatica.41.13

UDK: 821.163.42.09"15" 003.349 .1

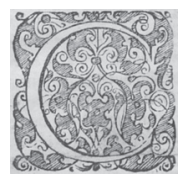

\title{
VELE LIPO I KORISNO KOMPILIRANJE - LIBER DE MODO BENE VIVENDI AD SOROREM U GRŠKOVIĆEVU ZBORNIKU IZ 16. STOLJEĆA
}

\author{
Andrea Radošević \\ Staroslavenski institut, Zagreb \\ aradosevic@stin.hr
}

U glagoljskim zbornicima nalazimo prijepise starijih kompiliranih tekstova, ali i tekstove za koje s većom vjerojatnošću možemo reći kako su nastali pisarevim kombiniranjem ranije poznatih djela. Vele lip kapitul $i$ koristan, neistražen didaktični tekst iz Grškovićeva zbornika, pripada drugoj spomenutoj skupini zborničkih tekstova. Utvrđeno je kako je Kapitul nastao kompiliranjem dvaju srednjovjekovnih tekstova koji su u hrvatskoj sredini bili poznati još u 15. stoljeću: 1 . starijega hrvatskog prijevoda poglavlja $D e$ timore Dei i De charitate Pseudo-Bernardova latinskoga djela Liber de modo bene vivendi ad sororem i 2 . kratke zbirka sentencija. Istraživanje je pokazalo kako je dodavanje zbirke sentencija prijevodu latinskoga traktata utjecalo na intenziviranje moralne pouke te je donekle približilo tekst propovjednom žanru. Vele lip kapitul $i$ koristan, uz već poznate glagoljske i latinične prijepise, još je jedna potvrda raširenosti latinskoga traktata Liber de modo bene vivendi ad sororem $\mathrm{u}$ hrvatskoj književnosti.

Ključne riječi: vernakularna književnost, kompiliranje, Grškovićev zbornik, Liber de modo bene vivendi ad sororem 


\section{UVOD}

Tekst Vele lip kapitul i koristan (dalje Kapitul) iz Grškovićeva zbornika (f. 185-189, or. 191-195) dosad nije bio predmetom istraživanja. U sklopu opisa sadržaja Grškovićeva zbornika Štefanić (1970: 51) navodi kako je riječ o "govoru o strahu božjem i ljubavi prema Bogu", no nigdje se ne spominje njegov mogući strani predložak niti se upućuje na postojanje paralelnoga teksta u nekom drugom kodeksu. Grškovićev zbornik glagoljski je kodeks raznolika sadržaja iz druge polovice 16. st. koji je najvjerojatnije nastao u Istri (Štefanić 1970: 51; Reinhart 2010: 670). ${ }^{1}$ Nazvan je prema vlasniku župniku Ivanu Grškoviću od kojega je JAZU 1934. otkupila rukopis koji se danas čuva u njezinu Arhivu pod sign. VII 32. U njegovu sastavu nalaze se brojni tekstovi koje poznajemo iz starijih glagoljskih kodeksa, među kojima pretežu oni iz Petrisova (1468.) i Vinodolskog zbornika (poč. 15. st.). Nezanemariva podudarnost u sadržajima navedenih dvaju zbornika - J. Reinhart (2012: 212-213) navodi čak 11 podudarnih tekstova s prvim te $10 \mathrm{~s}$ drugim zbornikom - ponukala me da za mogućim paralelnim starijim tekstom Kapitula počnem tragati na listovima navedenih dvaju rukopisa. Poznato je naime kako se u zbornicima iza različitih naziva nerijetko skrivaju isti tekstovi, kao što različiti tekstovi koji obrađuju sličnu tematiku znaju imati gotovo iste naslove (Dürrigl 2007: 81).

Usporedba Kapitula s Petrisovim zbornikom potvrdila je pretpostavku o mogućoj podudarnosti Grškovićeva teksta s najvećim i nezaobilaznim kodeksom hrvatske srednjovjekovne književnosti. Istraživanje je pokazalo kako je Kapitul kompilacija dvaju starijih tekstova iz 15. stoljeća: prve dvije trećine Kapitula (f. 185r-188r) odgovaraju tekstu S(lovo) s(ve)t(a)go Brnarda ot straha iz Petrisova zbornika (f. 4v-7r), a posljednji dio Kapitula (f. 188r-189r) odgovara tekstu sastavljenu od moralističkih sentencija koji je također zabilježen u Petrisovu zborniku (f. 238-239). Točnije riječ je o tekstu koji V. Štefanić i E. Hercigonja opisuju kao malu zbirku moralističke aforistike. ${ }^{2} \mathrm{Na}$ temelju ove usporedbe utvrđen je strani predložak većega dijela Kapitula, tj. dio koji se podudara s tekstom S(lovo) s(ve)t(a)go Brnarda ot straha iz Petrisova zbornika (4v-7r) prijepis je dijela starijega hrvatskog

1 E. Hercigonja smatra kako je rukopis nastao na frankopanskim posjedima u blizini čakavsko-kajkavskog područja (1983: 347-348).

2 Štefanić 1960: 382; Hercigonja 1975: 394. 
prijevoda latinskoga traktata Liber de modo bene vivendi ad sororem, koji je poznat pod nazivom Ovo su knige b(la)ž(e)n(a)go Brnarda opata (1r-23r).

\section{LIBER DE MODO BENE VIVENDI AD SOROREM}

Latinski traktat Liber de modo bene vivendi ad sororem (dalje Liber) u srednjem vijeku često se povezivao s imenom Sv. Bernarda iz Clairvauxa (1090-1153). Sumnje u njegovo autorstvo pojavljuju se u 17. stoljeću. Tako Jean Mabillon pripremajući izdanje cjelokupna opusa ovoga istaknutoga cistercita uključuje Liber u njegov sastav, ali ga smješta unutar odjeljka Opera supposititia et aliena. ${ }^{3} \mathrm{U}$ istom stoljeću Charles de Visch, ${ }^{4} \mathrm{u}$ katalogu u kojem je popisao rukopise iz Clairvauxa, djelo pripisuje cistercitu Thomasu iz Beverleya (oko 1150. - oko 1225). ${ }^{5}$ Ova se tvrdnja može naći u pojedinim studijama (Kuczynski 1995: 88; Newman 1989: 139-140) i leksikografskim izdanjima, ${ }^{6}$ dok proučavatelji opusa Thomasa iz Beverleya (E. Mikkers, P. G. Schmidt) odbacuju njegovo autorstvo (Mouron 2014: 5). Iako se uz naziv traktata katkad pojavljuje ime Sv. Bernarda, Liber se danas uglavnom smatra anonimnim djelom koje je nastalo iz pera učena redovnika. U literaturi se uglavnom navodi kao Pseudo-Bernardov traktat. Anne Mouron, najbolja poznavateljica ovoga djela, na temelju istraživanja i uspoređivanja traktata s njegovim uzorima, među kojima istaknuto mjesto zauzima Expositio in regulam beati Augustini, zaključuje kako je autor najvjerojatnije pripadao Redu Sv. Augustina (Mouron 2014: 5-6).

Za višestoljetno pripisivanje traktata Sv. Bernardu moguće je naći nekoliko objašnjenja. Prvo, pripisivanje djela istaknutim velikanima srednjovjekovlja ne samo da je ojačavalo autoritet nekog teksta nego je zasigurno poboljšavalo njegovu recepciju. Drugo, na Liber je snažno utjecalo čuveno djelo Sv. Bernarda iz Clairvauxa Sermones supra Cantica Canticorum, za koje se pretpostavlja da je napisano između 1135. i 1153. godine. Na temelju pretpostavke kako je traktat vjerojatno nastao neposredno nakon pojave

\footnotetext{
Mouron 2014: 5.

Pinder 2001: 176.

5 Mouron 2012: 301. Thomas iz Beverleya ili Thomas iz Froidmonta poznatiji je kao autor Životopisa Sv. Thomasa Becketa.

6 Bloomfield 1979: 161-162; Ogilvie-Thomson 2000: 50; Sharpe 1997: 641-642. Prema Mouron 2014: 5 .
} 
navedenoga djela Sv. Bernarda kao donja se granica njegova nastanka uzima 1160, a kao gornja granica uzima se vrijeme iz kojeg potječe dosad najstariji poznati rukopis, a to je sredina 13 . st. $^{7} \mathrm{~S}$ obzirom na to da se u traktatu nigdje ne navodi popis sedam smrtnih grijeha ili darova Duha Svetoga, koji se nakon IV. lateranskog koncila održanog 1215. spominju u većini katehetskih tekstova, A. Mouron zaključuje kako je Liber vjerojatno nastao prije 1215 , tj. najkasnije početkom 13. st.

Liber de modo bene vivendi ad sororem nastavlja dugu tradiciju pisanja didaktične literature namijenjene duhovnom uzdizanju žena koje svoj život posvećuju Kristu, tradiciju koja svoje korijene vuče još iz doba kasne antike: Ambrozije (De virginibus ad Marcellinam sororem suam), Cezarije iz Arlesa (Regula ad virginum) i Jeronim (Epistola XXII, Ad Eustochium) (Mouron 2014: 3). Ta će literatura svoj procvat doživjeti tijekom 12. i 13. stoljeća, i to kao odgovor na sve veću potrebu redovnica da im se sastave upute za kontemplaciju (Newman 2012: 379-381). Među najpoznatijim djelima te vrste navodim sljedeće: Pisma Abelarda i Heloize, De institutione inclusarum Aelreda iz Rievaulxa, Ancrene Wisse, Speculum virginum, Liber de modo bene vivendi i dr. (Newman 1989: 112-114; Mouron 2000: 93).

Riječ je o traktatima i priručnicima u kojima je narator uglavnom muški redovnik koji iz pozicije mudra učitelja i dobra poznavatelja Biblije i drugih autoriteta daje niz uputa o krepostima, bitnim učenjima, ali i zamkama koje bi se redovnicama mogle naći na putu njihova duhovnoga razvoja. Većina traktata dijeli sličan retoričko-stilski aparat na način da se didaktičnost redovito pojačava izravnim pitanjima, razvijanje pojedinih tema i njihovo argumentiranje nerijetko se temelji na raznim figurama ponavljanja, ${ }^{8}$ a većina prologa sadržava vrlo slične formulacije: "Draga sestro, mnogo godina molila si me da sastavim pravila."

Liber je oblikovan kao traktat sastavljen od 73 poglavlja u kojima se tematiziraju pojmovi čije je ispravno shvaćanje preduvjet željena duhovnoga razvoja kao što su vjera, milosrđe, ljubav prema Bogu i bližnjemu, strah Božji i dr. ${ }^{10}$ Iako se među nazivima poglavlja pojavljuju različite teme poput tumačenja kreposti i grijeha, posvećenog života, ispovijedi, pokajanja, njima

\footnotetext{
Mouron 2014: 5-6.

8 Mouron 2000: 90.

9 Gotovo ista formulacija pojavljuje se u prolozima djela: Liber de modo bene vivendi, De institutione inclusarum i Ancrenne Wisse (Mouron 2000: 82).

10 Kuczynski 1995: 88.
} 
nije posvećena jednaka pozornost. Poglavlja o grijesima (De avaritia, De cupiditate, De ira, De superbia) redovito su vrlo kratka, za razliku od znanto duljih poglavlja u kojima se primjerice objašnjava kontemplacija (De activa et contemplativa vita).

Liber je refleksivno djelo u kojem se nizanjem uputa i savjeta u svrhu postizanja posvećenosti, pridraga sestrica potiče na razmišljanje. Modus uvjeravanja svodi se na apeliranja, upućivanja i osnaživanja iskaza brojnim biblijskim citatima, tj. svodi se na ono što se zove rationes i auctoritates, ${ }^{11}$ dok se uvjeravanje u obliku exempla vrlo rijetko pojavljuje. Štoviše, pođemo li od toga kako kod navođenja biblijskih citata najčešće izostaju citatne najave, tj. da se njihova pojava rijetko eksplicitno ističe, možemo zaključiti kako se većina uvjeravanja temelji ipak na iznošenju argumenata i poticaja na daljnje razmišljanje o tome kako voditi dobar život i razvijati vrline. Prema toj se značajki Liber razlikuje od nekih sličnih djela namijenjenih uvođenju redovnica u duhovan život, poput vrlo popularnog teksta Ancrene Wisse koje je obilovalo konkretnim uputama i primjerima iz svakodnevice. ${ }^{12}$

Thus in the Manner (English translation of Liber) the reader is taught to reflect and turn to her mind, rather than to her imagination or her experience of everydaylife. (Mouron 2012: 97) // U tekstu Manner (engleskom prijevodu latinskoga djela Liber) čitatelja se potiče da se okrene vlastitome razumu, a ne imaginaciji ili iskustvima iz svakodnevnog života.

Iako primarno zamišljen kao vodič i upućivanje namijenjeno ženskoj publici, Liber je poput drugih sličnih traktata (Speculum Virginum, Ancrene Wisse), korišten i kao duhovni priručnik u muškim samostanima, ${ }^{13}$ ali i kao štivo u poučavanju pastve. Jedan od najstarijih rukopisa u kojem je sačuvan Liber, tj. rukopis iz 1267. koji se čuva u Nacionalnoj knjižnici u Madridu pod sign. 871, bio je prilagođen muškoj publici (Pinder 2001: 173).

$\mathrm{Na}$ temelju pretpostavke kako djelo nije upućeno imaginarnoj recipijentici, već stvarnoj osobi, neki su istraživači identitet redovnice poistovjećivali sa stvarnim sestrama mogućih autora traktata. Tako se nekad navodi

\footnotetext{
11 Pozivanje na biblijske i patrističke citate (auctoritates), nabrajanje razloga i dokaza (rationes) te unošenje narativnih egzemplarnih tekstova (exempla) predstavljali su tri temeljna načina argumentiranja u moralno-didaktičnih tekstovima. Delcorno 2000: 474; Bremond; Le Goff; Schmitt 1996: 30-31.

12 Mouron 2000: 90.

13 Kuczynski 1995: 88; Gunn 2008: 3.
} 
kako je Sv. Bernard Liber uputio svojoj sestri Humbelini koja je 1122. ušla u samostan (Mouron 2014: 1), a katkad se recipijenticom smatra Margareta iz Beverleya kao sestra Thomasa iz Beverleya, poznata i kao sudionica 3. križarskog rata. ${ }^{14}$ Ipak, kako autorstvo traktata do danas nije riješeno, utvrđivanje identiteta redovnice također ostaje otvorenim.

Poznato je i kako je Liber bio omiljeno štivo Sv. Brigite Švedske na njezinu hodočašću do Santiaga de Compostele (Pinder 2001: 176). Svoju najveću popularnost djelo je steklo u 15. i 16. stoljeću kada izlazi više tiskanih izdanja, od čega daleko najviše u Italiji (10), zatim Francuskoj (3), Španjolskoj (2) i u Engleskoj (1). ${ }^{15}$ To je i vrijeme njegova ulaska u europske vernakularne književnosti obilježeno prijevodima na talijanski, katalonski, srednjoengleski i dr. Ovomu se nizu već u 15. st. pridružuje i hrvatska književnost, i to djelomičnim prijevodom sačuvanim u Petrisovu zborniku, o čemu se govori u sljedećem odlomku.

\subsection{Liber de modo bene vivendi u hrvatskoj književnosti}

Hrvatska književnost 15. i 16. stoljeća poznaje dva prijevoda latinskoga traktata Liber de modo bene vivendi ad sororem: stariji je zasvjedočen u glagoljskim, a mlađi u latiničnim rukopisima. Stariji prijevod poznat pod nazivom Knige b(la)ž(e)n(a)go Brnarda Opata iz Petrisova zbornika (1468.) sadržava prvih 13 poglavlja. ${ }^{16}$ Riječ je o tekstu koji E. Hercigonja smatra "[...] primjerom prevodilačkog umijeća naših srednjovjekovnih pisaca, dokazom njihova suptilnoga osjećaja za vrednote jezika" (1975: 388).

Mlađi hrvatski prijevod poznat pod naslovom Nauci svetog Bernarda sestri svojoj nastao je vjerojatno u 16. st., a zabilježen je u latiničnim rukopisima: 1. I b 55 (Arhiv HAZU) iz 16. st. - nije sačuvan prolog i početak prve glave; 2. IV a 34 (Arhiv HAZU) koji je 1595. prepisao Marko Prodić u Kotoru; 3. I b 83 ili Lulićev zbornik (Arhiv HAZU) u čijem se sastavu nalazi prijepis 27. glave Ot ispovidi. Hrvatski prijevod sačuvan u rukopisima $I b$ 55 i $I V$ a 34 sadržava sva poglavlja latinskoga traktata, no većina ih je znatno skraćena.

14 Rice 2008: 21.

15 Mouron 2014: 2; Nekoliko talijanskih izdanja ovog djela danas se čuvaju u Dubrovniku: u Dominikanskom samostanu (35-II-3, adl. 1.; 35-II-12) i samostanu reda Male braće (B. Ink. 6., Ink. 12) te na Košljunu (F. Ink. 60). Badalić 1952: 66-67, br. 179-182.

16 Štefanić 1960: 359-360; Hercigonja 1975: 387-389; Sambunjak 1997. 
Dva se hrvatska prijevoda između ostalog razlikuju u adresiranju. ${ }^{17}$ Dok u mlađem prijevodu, kao i u latinskom traktatu nalazimo različita nijansiranja upućivanja pridragoj sestrici (charissima mihi in Christo soror, soror dilecta, honesta virgo; sestro pridraga), u starijem se prijevodu tekst obraća braći (o bratiê draga; bratiê moê draga), tj. pripadnicima klera u užem i cjelokupnoj pastvi u širem značenju. U starijem je prijevodu lat. traktat prvobitno upućen duhovnom razvoju redovnice pretvoren u poučno štivo namijenjeno katehezi i pastorizaciji. Unatoč brojnim razlikama zajedničko je obilježje obaju prijevoda isticanje pripadnosti autoritetu Sv. Bernarda.

Nauci svetog Bernarda sestri svojoj ranije su se na temelju Kukuljevićeva ${ }^{18}$ stajališta pokušavali pripisati Marku Maruliću, no njegovo autorstvo nije potvrđeno. ${ }^{19}$ Iako je Z. Pandžić (2009: 38-49) relativno nedavno pokušao dokazati kako je Kukuljevićeva tvrdnja o Maruliću kao prevoditelju ovoga djela točna, nije navedeno dovoljno primjera na temelju kojih bi se stajalište moglo potvrditi.

Latinski traktat Liber de modo bene viviendi katkad se navodi kao jedan od glavnih uzora Marulićevih Upućivanja u čestit život po primjerima svetaca, na što u svojem predgovoru Upućivanjima upozorava njihov priređivač i prevoditelj Glavičić. ${ }^{20}$ Drugačijega je mišljenja Charles Béné koji navodi kako sličnosti među dvama djelima nalazimo uglavnom u nekim vanjskim osobinama: broj poglavlja, djelomice naziv djela kao i nazivi nekih poglavlja, dok usporedba samoga teksta lat. traktata i Marulićevih Upućivanja pokazuje kako se djela podosta razlikuju:

Prvo i najvažnije mjesto Marulić daje primjerima, uvjeren da su primjeri učinkovitiji od savjeta. Vrlo kratka poglavlja Pseudo-Bernarda sastoje se uglavnom od

17 "Draga moe sestro va Isuhrsti I prevzljublena moe brat'e svetoga profesa, dalje se više ne spominju sestre već uvijek samo brate" (Hercigonja 1975: 388).

18 "Od ovih naukah (op.a. "Nauci sv. Bernarda k sestri svojoj”), koji su prevedeni iz latinskoga, sačuvana su tri rukopisa, a u četvrtom sborniku Lulićevu ima glava 27 “Od ispovidi” [...] Moralni sadržaj, kao i slog hrvatskoga jezika u ovom prijevodu, najbolji su dokazi da je ovo djelo zbilja Marulićevo" (Kukuljević 1869: LXXVI).

19 "Osim Naslidovanja, u kojem se na kraju rukopisa potvrđuje Marulićevo ime, Kukuljević bez izravnoga dokaza pripisuje Maruliću Nauke sv. Bernarda k sestri svojoj”" (Kolumbić 1990: $85)$.

20 "Jedan od mogućih glavnih poticaja i uzora (iako ga pisac ne spominje znamenito je i u ono doba Bernardu iz Clairvauxa pripisivano djelo Modus (ili De modo) bene vivendi. Na tu mogućnost upućuje ne samo blizak opći naslov nego i podjela sadržaja na također sedamdesetak poglavlja od kojih mnoga nose naslove na koje Marulićevi uvelike podsjećaju” (Glavičić 2010: XVII-XVIII). 
duhovnih savjeta; primjeri su rijetki, pri čemu često samo jedan uzor utjelovljuje ovu ili onu krepost. Duh djela različit je. Pseudo-Bernard posvećuje znatan broj poglavlja grijesima koje treba izbjegavati ili iskušenjima koja uznemiruju kršćanina. Marulić poglavito ističe kreposti (Béné 1998: 174).

Neovisno o stupnju njihove različitosti i pitanju jačine utjecaja lat. djela Liber je vjerojatno bio dio njegove lektire. S obzirom na to da se talijanska izdanja lat. traktata pojavljuju u 15. st., nije nemoguće da je jedno od njih dospjelo i u Marulićeve ruke.

\subsection{Liber de modo bene vivendi u Grškovićevu zborniku}

Kapitul iz Grškovićeva zbornika, točnije njegov veći dio, ovim se radom pridružuje prijepisima starijega hrvatskog prijevoda lat. traktata Liber de modo bene vivendi. Tako prve dvije trećine Kapitula predstavljaju kombinaciju prijevoda odabranih dijelova poglavlja IV. De timore Dei ${ }^{21}$ (prevedeni su 7, 8. i 9. odlomak, ali ne i odlomci 10. i 11.) i V.De charitate $^{22}$ (prevedeno je posljednjih desetak redaka 12. odlomka, 13. i 14. odlomak). Od istih se odlomaka poglavlja o strahu Božjem i poglavlja o ljubavi sastoji tekst S(lovo) s(veta)go Brnarda ot straha iz Petrisova zbornika. Zanimljivo je kako se u navedenom rukopisu sljedeći tekst Slovo s(veta)go Brnarda opata od ljub've svršene (7r-9r) također sastoji od prijevoda 12, 13. i 14. odlomka lat. poglavlja De charitate, tj. Petrisov zbornik sadržava dva zaredom prepisana poglavlja o ljubavi, i to jedanput kao samostalan tekst, a jedanput kao dio teksta o strahu Božjemu.

U Grškovićevu zborniku, za razliku od Petrisova, u naslovu ne doznajemo ništa o tematici teksta. Znamo samo kako slijedi lip kapitul $i$ koristan. Epitet lip mogao bi se osim na lip i dobar nauk nekog autoriteta, odnositi i na lipo kompiliranje, tj. na lipo sastavljen kapitul. Riječ kapitul ostatak je prepisivanja starijeg prijevoda u kojem svako poglavlje u naslovu sadržava riječ kapitul i redni broj koji se gotovo uvijek podudara s rednim brojem poglavlja lat. traktata (u Petrisovu zborniku tekst je naslovljen kao $S$ (lovo) s(veta)go Brnarda ot straha $k(a) p(i) t(u l) \cdot \widetilde{g} \cdot(=4)$ što odgovara naslovu 4. poglavlja De timore Dei). Pisar je tako vjerojatno iz starijega predloška

\footnotetext{
21 PL 184, 1203C-1205B.

22 PL 184, 1207A-1208D.
} 
preuzeo kapitul kao oznaku za tekst, dok je informaciju o sadržaju zamijenio onom o njegovoj korisnosti.

\section{KOMPILIRANJE U GRŠKOVIĆEVU ZBORNIKU}

Na pragmatičnost (utilitarnost) i kompilativnost, kao dvije bitne i često neraskidive značajke hrvatske srednjovjekovne književnosti, već je odavno upozoreno (Hercigonja 1975; Fališevac 1980, 2007; Dürrigl 2007; 2010). Iako se katkad čini kako je podsjećanje na njih "suvišno", ponavljanje dobro poznate prakse tvoraca starijih tekstova, koji su prema svojim potrebama strana djela prilagođavali ciljanoj publici, koji su sastavljali nove tekstove spajanjem starijih prijepisa u cjelovitu ili izmijenjenu obliku, ${ }^{23}$ svako je novo otkriće povod da se na temelju odabranoga djela prouči odnos pisara/ kompilatora prema starijim predlošcima. Nemogućnost da se tomu odupremo uvelike raste kada pred sobom imamo tekst čija se pragmatičnost najavljuje već u naslovu (Počine vele lip kapitul $i$ koristan) te čija analiza ne može biti u potpunosti provedena ne samo bez usporedbe sa starijim predlošcima nego i bez utvrđivanja odnosa starijih predložaka prema cjelini iz koje su preuzeti, tj. prema tome pripadaju li nekomu opširnijem tekstu ili su zapisani kao samostalni tekstovi. Opravdanost je tim veća kada oba predloška i kompilirani tekst pripadaju zbornicima čiji se sadržaj podudara u više od desetak tekstova. Jedno od objašnjenja tolike podudarnosti moglo bi se naći u Hercigonjinu stajalištu o postojanju "odgovarajućih fondova rukopisa (po samostanima ili pri glagoljaškim 'kapitulima') koji su služili piscima kao predlošci koje su kopirali i prevodili”" (Hercigonja 1983: 165).

U glagoljskim zbornicima nalazimo tekstove koji predstavljaju prijepise već kompiliranih tekstova i tekstove za koje s većom vjerojatnošću možemo reći kako su nastali pisarevim kombiniranjem ranije poznatih djela. U Kapitulu iz Grškovićeva zbornika, koji je nastao spajanjem dvaju glagoljskih tekstova iz 15. st., jasno se ocrtavaju stariji i novi slojevi kompiliranja. Tako ostatke starijeg kompiliranja, koje je pisar vjerno prenio, nalazimo u onom dijelu Kapitula koji se podudara sa starijim hrvatskim prijevodom lat. traktata iz Petrisova zbornika. Ponavljam, riječ je o kompilaciji IV. i V. poglavlja traktata za koju je teško utvrditi pojavljuje li se tek u hrvatskom prijevodu

23 Hercigonja 1975: 330; Dürrigl 2010: 224. 
ili je postojala u nekoj stranoj preradi koja je hrvatskomu prevoditelju poslužila kao predložak. Novi sloj kompiliranja koji obuhvaća već spomenuto spajanje starijega prijepisa Pseudo-Bernardova teksta s kratkom zbirkom sentencija, predmet je istraživanja ovoga rada.

Prijevod Pseudo-Bernardova traktata koji je došao do pisara Grškovićeva zbornika već je bio namijenjen široj publici (braći). Jedan od odlomaka poslužio mu je kao polazište u sastavljanju moralističke upute koja poučava vrijednostima koje strah od Boga i ljubav donose u zajedništvu s mudrosti. No iako se lat. traktat i stariji hrvatski prijevod iz Petrisova zbornika razlikuju u adresiranju, među njima nema većih razlika u modusu uvjeravanja ciljane publike. Budući da je Liber, poput ostalih sličnih djela prvotno bio namijenjen redovnicama koje su napustile vanjski svijet odlučivši se za onaj iza samostanskih zidina, to je poučan tekst trebalo prilagoditi novoj publici koja se svakodnevno susreće s brojnim iskušenjima, odnosno kako recipijent više nije posvećena dumna koja žudi za duhovnim vodičem, već pastva ili mlađi duhovni pomladak, razna učenja trebalo je konkretizirati na drugačijoj razini. Namjera da se i modus uvjeravanja prilagodi novoj publici (braći) temeljna je značajka i novina Grškovićeva Kapitula. Kako je već rečeno, lat. traktat prilično je oskudijevao u navođenju egzempla i prilikâ iz svakodnevice bliskih običnomu puku, tj. u onim kratkim narativnim formama s kojima su se pripadnici glagoljaške zajednice (pisari, kompilatori, čitatelji/slušatelji) nerijetko susretali. Izostanak takvih primjera u Grškovićevu Kapitulu nastojao se nadomjestiti spajanjem Pseudo-Bernardova teksta s moralnih izrekama u kojima se iznose konkretni savjeti.

Proširenje proznih tekstova izrekama iz Knjige mudrosti, Mudrih izreka, Propovjednika i Knjige Sirahove na način da se njima pojačava moralna pouka nije rijetkost u hrvatskoj književnosti. Više su nego poznati primjeri njihova unošenja u prijevod istočne Priče o premudrom Akiru ${ }^{24}$ ili prijevoda Knjige Kata mudroga (Disticha Catonis) ${ }^{25}$ čiji je antički sadržaj znatno kristijaniziran. S obzirom na to da Grškovićev zbornik sadržava više različitih moralno-didaktičnih djela, pisar/kompilator mogao je već prema poznatu običaju unošenja mudrih citata intervenirati u sadržaj, a time i konačno značenje Kapitula. Kratka zbirka sentencija, koja je ujedno treći dio Kapitula, u izboru i redoslijedu navođenja jednim se dijelom podudara s nizom izreka

\footnotetext{
24 Badurina Stipčević 2013: 3; 2015: 381.

25 Maxiner 1885: 91.
} 
kojima počinje prvo Akirovo obraćanje Anadanu u Priči o premudrom Akiru u kojem iznosi upute za dobar život: Prvo načelo prêmudrosti est' strah' g(ospodb)nb. Po tom' budi skor slišati A kasan' govoriti u gnevê trpêliv' (CPet, 96v). ${ }^{26}$ Ovaj kratki isječak koji se u istom obliku pojavljuje kao dio narativne proze (Priča o premudrom Akiru), dio refleksivnog teksta (Kapi$t u l$ ), ali i kao dio zbirke sentencija (Petrisov zbornik) vjerojatno je potjecao iz nekog florilegija koji je bio poznat među sastavljačima srednjovjekovnih tekstova.

U ovom radu pokušat će se odrediti uloga kratke zbirke sentencija u sastavu Grškovićeva teksta, tj. jesu li one samo dodatak ili, ipak, donekle mijenjaju žanrovsku sliku Pseudo-Bernardova odlomka s kojim se spajaju u vele lip kapitul.

\subsection{Grškovićev Kapitul - odlomak traktata ili tematska propovijed}

Oba teksta od kojih je sastavljen Kapitul pripadaju refleksivnoj, tj. moralnodidaktičnoj srednjovjekovnoj prozi. Spajanjem traktata i kratke zbirke sentencija stvoren je tekst koji najviše žanrovskih značajki dijeli s tematskom propovijedi (sermonom). Povezivanje traktata s propovijedi temeljim na njihovu djelomičnom žanrovskom preklapanju, ali i na tome da je Liber katkad bio prepisivan i tiskan pod nazivom sermon (Sermoni devotissimi del devotissimo sancto Bernardo a una sorella monacha, Venezia, 1508) te da se u nekim studijama znao povezivati s propovjednom prozom. ${ }^{27}$ Kapitul se tako može opisati kao trodijelna propovijed koja se sastoji od uvoda, razrade dvaju bitnih teoloških pojmova (strah Božji i ljubav) koja obuhvaća njihova tumačenja uključujući i pozivanja na autoritete te od završnog dijela u kojem se konkretiziraju općenite tvrdnje iznesene u prethodnom dijelu teksta.

26 Badurina Stipčević 2015: 388-389.

27 "The Liber may be seen as a didactic work and one which reminds the reader of a collection of sermons. A regular feature of the text is to begin most chapters with biblical quotations and to end them with the voice of the preacher. It is not suprising, therefore, that early printed editions of the work usually refer to each chapter as a "sermo"" (Mouron 2014: 3). // Latinski tekst Liber može se opisati kao didaktično djelo koje čitatelja podsjeća na zbirku propovijedi. Većina poglavlja u pravilu počinje biblijskim citatima te završava glasom propovjednika. Stoga ne iznenađuje što su u ranim izdanjima ovoga teksta poglavlja nazvana propovijedima (sermonima). 
Prvi dio Kapitula, koji odgovara prijevodu 7. odlomka lat. traktata, zapravo je produžena thema na čije se pozorno slušanje i razumijevanje upozorava u uvodnom obraćanju ( $O$ bratiê draga, slišite ča vam' govorim', $i$ zato vas spominam razumiite ča vam pravlu). Thema se otvara upozorenjem kako se Boga vazda boêti imamo zvrhu vsega i zapovedi nega obslužiti, nakon čega slijedi niz sintaktičkim paralelizmom povezanih starozavjetnih citata, većinom iz Knjige Sirahove, kojima se osnažuju tvrdnje o veličini straha Božjega te se nabrajaju sve dobrobiti bogobojaznosti. Nakon neprekinuta niza od dvadesetak citata čija je funkcija bila uvjeravanje u snagu straha Božjega i ljubavi slijedi središnji dio Kapitula koji je posvećen njihovu ispravnom shvaćanju.

Za razliku od prvog dijela koji se gotovo potpuno temelji na biblijskom tekstu, u središnjem dijelu iznose se tumačenja koja se tek povremeno očvršćuju pozivanjem na Sveto pismo. U ovom je dijelu Pseudo-Bernardov tekst znatno pojednostavljen na način da je problematizacija straha Božjega doslovce prepolovljena, a pozivanja na pojedine autoritete su izostavljena. Točnije Grškovićev Kapitul iz starijega je prijevoda naslijedio tumačenje samo dviju vrsta straha Božjega, od ukupno četiri vrste koje se opisuju u lat. traktatu, a čije se problematiziranje najavljuje kako u Grškovićevu (Bratiê draga v Krsti Isusi esu četiri strasi), tako i u Petrisovu zborniku (O mố draga bratê, va Is(u)h(rbst)i esu četiri strahi, 5v). Štoviše, u obama se rukopisima opis drugoga straha prekida citatom Ps 5,12 iz 9. odlomka, koji se potom povezuje s navodom Pj 8,6 iz drugoga dijela 12. odlomka V. poglavlja De charitate. Navedena su dva citata, tj. dva poglavlja, u jednu cjelinu povezana sintaktičkim paralelizmom (I zato piše): I zato piše prorok' proslavet' se o tebi vsi ki lûbe spasenie /Ps 5,12/ I zato pišse Solomunv kantiki mocan' est kako i semrt' ka silu razdili dušu ot teloa /Pj 8,6/ (CGrš, 186v). Strah Božji tumači se kroz objašnjavanje njegova odnosa prema mudrosti (Strah Boži est istočnik' mudrosti; strah' Boži čini mudra čl(ovê)ka; strah gospodan est mudrost' i nauk'), ljubavi i grijehu (niedna rič ni čin' nas čistih' ot griha kako strah' Boži i lubav Božiê, kada se za lûbav Božiû ot' griha čuvamo; Boga se e boêti, niedno zlo ne činiti). Iz starijega su prijevoda također naslijeđene promjene u načinu obraćanja recipijentu: $u$ latinskom traktatu riječ je većinom o tihim obraćanjima dragoj sestrici kojoj se iznose upute za ispravnu kontemplaciju, dok obraćanja braći u Kapitulu podsjećaju na adresiranja kakva poznajemo iz propopovijedi, a koja su nerijetko sadržavala različite imperativne oblike. 
Stavljanje znatno većega naglaska na uvjeravanje i naknadno djelovanje $^{28}$ nego na detaljno tumačenje i argumentiranje još je jedna značajka koja Kapitul približuje propovjednomu žanru. Retorički postupci uvjeravanja uključivali su obraćanja publici, prožimanje teksta već spomenutim imperativnim oblicima (apelima, naredbama) kao i oprimjeravanja tvrdnji kratkim narativnim formama. Cilj je bio raznim primjerima publici približiti prethodno iznesena tumačenja apstraktnih pojmova. U Kapitulu, točnije u njegovu 3. dijelu, tu funkciju zauzima zbirka sentencija. Takav izbor nije teško objasniti, što zbog već postojeće navike da se različiti tekstovi prošire citatima iz mudrosnih knjiga, a što zbog temeljnog obilježja sentencija, a to je da se njima iznose oprimjerena iskustva.

\subsection{Zbirka sentencija u Grškovićevu Kapitulu}

Uloga zbirke sentencija kao 3. dijela Kapitula sastojala se ne samo u konkretiziranju općih tvrdnji iznesenih unutar rasprave o strahu Božjem i ljubavi prema Bogu (ki pravo živut i zapovedi nega obslužiti), nego i u intenziviranju značenja cijeloga teksta. Posezanjem upravo za sentencijama, pisar/kompilator istodobno je riješio pitanje spomenute konkretizacije, ali i pitanje uvjeravateljske funkcije teksta s obzirom na to da se većina sentencija pojavljuje u obliku apela i zapovijedi. Unošenje sentencija pomoglo je kompilatoru da bez velikih promjena unutar samih tekstova sastavi uvjeravateljski poučan tekst blizak široj publici.

Kratka zbirka sentencija s Pseudo-Bernardovim je tekstom spojena unošenjem dviju Pavlovih poslanica koje imaju ulogu kompilacijske poveznice, $\mathrm{tj}$. uvođenje sentencija provedeno je oslanjanjem na autoritet Svetoga pisma. U Kapitulu se završno obraćanje braći iz Pseudo-Bernardova teksta, u kojem se pozivaju na usvajanje učenja o ljubavi (Tada, bratiê, lûbimo B(og)a v sem životi da nas' pomilue otac' nebeski v cesarastvom' nebeskom', slišite ča s(ve)ti Paval govori, CGř̌; A tada, draga moê bratê, lûbimo $B(\mathrm{og})$ a v tom' životê da nas polûbi $B(\mathrm{og})_{b}$ ot $(a) c$ sa sinom' v c(êsa)rstvê $n(e) b(e) s k o m$. Amen', CPet), pretvara u novo obraćanje (slišite ča s(ve)ti Paval govori), i to na način da se ponavlja isti citatni obrazac kao u prethodnoj rečenici u kojoj se navod iz Ivanova evanđelja najavljuje riječima: Slišite

28 Djelovanje teksta na recipijenta nakon njegove izvedbe (slušanje, čitanje) jedna je od temeljnih značajki uvjeravateljskih žanrova (Zlatar 2001: 80). 
$\check{c ̌ a}$ sam Isuhrst reče. Tako se sintaktičkim paralelizmom dva citata, koji započinju imperativnim pozivanjem na slušanje, povezuju u jednu cjelinu. No povezivanje nije provedeno samo na sintaktičkoj, nego i na tematskoj i citatnoj razini. Na tematskoj se razini prva poslanica o ljubavi izravno povezuje s prethodnim odlomcima Pseudo-Bernardova traktata u kojima se tumači pojam ljubavi, dok druga poslanica, tj. Pavlova poslanica Galaćanima o opasnostima prepuštanja tjelesnim užicima (ne lûbiti suetnih' vika sego ni gizde ni pohoti tela ni nenanvisti ni protivcin mê̂ bratiû), predstavlja prijelaz s učenja o ljubavi na konkretiziranje grijeha koji će se, između ostalog, navoditi u mudrim izrekama. Dvije pak tematski različite poslanice povezane su na citatnoj razini budući da obje pripadaju istomu izvoru, Svetomu Pavlu. Nabrajanje opasnosti tijela iz Pavlove poslanice tako otvara mogućnost spajanja traktata s mudrim izrekama u kojima se iznose savjeti kako ih izbjeći u svakodnevnom životu. Oponašanje prethodne najave citata, zatim odabir citata čija se tema podudara s temom odlomka na koji se nadovezuje (ljubav), kao i to da je riječ o autoritetu (sveti Paval) koji se također spominje u prijevodu lat. odlomka, više nego očito upućuje na poman odabir ove poveznice.

Objašnjenje za izbor sentencija kao 3. dijela Kapitula moglo bi se, uz već navedene razloge, naći i u samom sastavu Pseudo-Bernardova poglavlja, točnije u njegovu uvodu koji se gotovo u cijelosti sastoji od citata iz mudrosnih knjiga, ponajviše iz Knjige Sirahove. Naime niti jedno poglavlje lat. traktata, od njih ukupno 73, u tolikoj mjeri ne crpi građu iz mudrosnih knjiga kao što je slučaj s poglavljem o strahu Božjem. ${ }^{29}$ Unošenjem sentencija koje se većinom sastoje od navoda iz Knjige Sirahove, Propovjednika i Mudrih izreka i na citatnoj se razini moglo provesti plodonosno kompiliranje dvaju tekstova. Završavanje teksta sentencijama kojima su se konkretizirale opće tvrdnje iz uvoda Kapitula (Boga se boêti, niedno zlo ne činiti) imalo je primaran cilj jačega djelovanja na slušatelje.

Kako je rečeno, prilagođavanje modusa uvjeravanja obuvaćalo je uvođenje jačih retoričko-stilskih sredstava, i to u obliku upozorenja i apela. Kapitul naime ne završava kao Pseudo-Bernardov tekst navođenjem kraljevstva nebeskog kao nagrade za krepostan život (da nas polûbi B $($ og) ot $(a) c$ sa sinom' v c(êsa)rstvê n(e)b(e)skom. Amen', CPet), nego upravo suprotno,

29 Poglavlja XI. De tristitia i XVIII. De disciplina također sadržavaju više mudrih izreka iz Svetog pisma, ali niti približno kao poglavlje o strahu Božjemu. 
zastrašivanjem i upozorenjem na mogućnost Božjeg zatvaranja rajskih vrata (da gospodin' B(og) tebi ne zatvori vrat' raiskih') što očekuje one ki se boga ne boe i ki ne obslužuju zapovedi nega. U Kapitulu se tako u raspravu o odlasku u carstvo nebesko, do kojeg vode strah Božji i ljubav (Ki se B(og)a boi dobro bude imel na konci v životi i v semrti svoei bude blažen') unosi objašnjavanje i konkretiziranje stvari koje bi se čovjeku mogle ispriječiti na tom putu. Dok je u latinskom tekstu težište na utvrđivanju zamki koje bi redovnicu mogle udaljiti od duhovnog uzdizanja, poput pogrešnog shvaćanja temelja vjere (npr. straha Božjega), u Kapitulu se nižu anaforički povezani savjeti kojima se podsjeća na opasnosti nesmotrenog života: ne imii družbu sa ženu lûkavu da ne izgorišs ognem ee, ne pit vina mnog da te ne povrati v norost', ne iji vele krat' va dne, a koje se pojavljuju tamo gdje nema straha Božjega (da kadi straha ni ondi e pogibel' duši, kadi ni straha tu e rasprostranstvo života i ondi e obilie griha).

Pretvaranje zbirke sentencija u 3. dio Pseudo-Bernardova teksta uključivalo je pojedine promjene unutar sastava zbirke. Usporedba Grškovićeva i Petrisova zbornika pokazala je kako su u Kapitul većinom ušli oni dijelovi sentencija u kojima se iznosila naredba ili uputa, uz istodobno izostavljanje objašnjenja. Takvo je nizanje konciznih izreka imalo svrhu učinkovita uvjeravanja. Ovdje napominjem kako se predložak prema kojem su prepisivane izreke mogao razlikovati od teksta iz Petrisova zbornika, ali kako je ondje zapisan ipak nešto dulji i stariji prijepis, on je vrlo vjerojatno bliži izvorniku od Grškovićeva Kapitula. Isto tako u Petrisovu zborniku ispred pojedinih sentencija nalazimo grafičke oznake za poglavlja, što upućuje na to da je kratka zbirka sentencija vjerojatno pripadala nekomu većem florilegiju, odnosno da je predložak iz kojega je pisar Grškovićeva zbornika prepisivao sentencije bio dulji od paralelnoga teksta zapisanog u Kapitulu.

Osim navedenih kraćenja još je jedan postupak izravan pokazatelj prilagođenosti sentencija Pseudo-Bernardovu tekstu. Riječ je o pomnu odabiru završne sentencije koja se ne sastoji od iznošenja konkretne upute vezane za pojedino ponašanje, kao što je slučaj sa završetkom zbirke iz Petrisova zbornika (Ne budi sinu opiêvac' ni lûbodêini k' da ne obnicaš zač’ ki obniĉa v poruganii budê), nego od upućivanja konačnog apela kojim se braća na općoj razini pozivaju na razmišljanje o posljedicama ponašanja koje nije u skladu s kršćanskim učenjima. Riječ je o citatu iz Matejeva evanđelja (Ku meru budeš meriti tako se tebi budê meriti, Mt 7,2) kojim se istodobno zaokružuje ne samo treći dio teksta nego i Kapitul u cjelini. Treći dio Kapitula sastavljen većinom od navoda iz mudrosnih knjiga uokviren 
je tako dvama novozavjetnim citatima: Pavlovom poslanicom u kojoj se nabrajaju opasnosti služenja tjelesnim užicima na početku te svojevrsnim apelom iz Matejeva evanđelja na kraju trećega dijela. Na razini cijeloga Kapitula apel se dovodi u izravnu vezu s uvodnim navodom: Boga se vazda boêti imamo zvrhu vsega i zapovedi nega obslužiti.

Citatom iz Matejeva evanđelja možda se ponajviše podcrtava važnost samosvijesti. Iako Pseudo-Bernardov tekst i Kapitul imaju isti cilj, a to je potaknuti na razmišljanje, budući da su namijenjeni različitoj publici, trebalo je pribjeći uporabi nešto drugačijih sredstava uvjeravanja. Poticanje na razmišljanje ovdje se ne sastoji toliko od poticanja na duhovno uzdizanje, nego od sprječavanja konačna pada i zatvaranja rajskih vrata. Dok se u lat. traktatu velika pozornost posvećuje kontemplaciji u svrhu duhovnoga razvoja, ovdje se razvijanje samosvijesti ističe kao mjera opreza u skretanju s puta. Umjesto konačna obećanja kraljevstva nebeskog primatelji se zastrašuju Božjim zatvaranjem rajskih vrata.

Veći broj navedenih izreka koje se temelje na antitezi mudrost ludost (manen čl(ovê)k naglo pustiv' gniv, mudar že rasmotriv; budi skor slišati a kasan' otgovoriti; sin' mudar' veselit' oca, a sin' manen' pečal' materi svoei), pri čemu se ludost shvaća kao nepriznavanje Božjeg zakona ima ulogu korektiva ponašanja. Mudrost je opreka ludosti, ali i spavanju te donekle i lijenosti, tj. svim nesvjesnim stanjima u kojima nije moguća nikakva spoznaja o Božjima zapovijedima i njihovo usvajanje, a time ni vođenje života u skladu s kršćanskim načelima. Veličanje mudrosti, koje se pojavljuje kako u uvodu tako i završetku Kapitula, zapravo je pozivanje na razvijanje sposobnosti razlučivanja i osvješćivanja kako će se naš odnos prema bližnjima reflektirati na odnos s Bogom: kako budeš miril tako se $i$ tebi mirilo bude.

\section{ZAKLJUČAK}

Latinski traktat Liber de modo bene vivendi ad sororem iz 12./13. st. namijenjen duhovnomu razvoju redovnica u hrvatskoj se sredini, kao i u drugim europskim zemljama, koristio za pouku mladih duhovnika, ali i šire publike. Primjer je navedene prenamjene stariji hrvatski prijevod sačuvan u Petrisovu zborniku iz 15. st. u kojem su, uz promjene u adresiranju, neka opširna tumačenja Pseudo-Bernardova teksta pojednostavnjena. Na temelju jednoga poglavlja toga starijeg prijevoda i kratke zbirke sentencija (zapisane 
također na listovima navedenoga rukopisa) nastao je Vele lip kapitul $i$ koristan iz Grškovićeva zbornika, dosad gotovo neistražena kompilacija iz 16. st.

Pretpostavljajući kako zbirka sentencija nije samo dodana prijevodu lat. poglavlja nego da s njime čini cjelovit tekst donekle proširena značenja, uspoređeni su odnosi među dvama tekstovima Kapitula, kao i odnos između Kapitula i paralelnih tekstova iz Petrisova zbornika. Usporedba je pokazala kako je povezivanje sa zbirkom izreka bilo višestruko motivirano: 1 . nastojanje da se prijevod Pseudo-Bernardova teksta, u kojem se iznose općenite tvrdnje o strahu Božjem i ljubavi, obogati konkretnim primjerima bliskim širem broju primatelja, 2. povezivanje s uvodom Kapitula na tematsko-citatnoj razini, tj. uokviravanje Kapitula mudrim izrekama, 3. prilagođavanje modusa uvjeravanja široj publici unošenjem većeg broja apela i upozorenja.

Kompiliranjem je stvoren tekst koji najviše žanrovskih značajki dijeli $\mathrm{s}$ trodijelnom tematskom propovijedi, pri čemu ulogu egzempla, koji se u propovijedi unosio kako bi se oprimjerila prethodno iznesena tumačenja, preuzimaju mudre izreke. U prilog promijenjene žanrovske slike ide i to da je u Kapitulu, u odnosu na Pseudo-Bernardov tekst, znatno veći naglasak stavljen na uvjeravanje i zastrašivanje nego na detaljno tumačenje pojmova, što osobito do izražaja dolazi u 3. dijelu, gdje se često krate objasnidbeni dijelovi sentencija s ciljem stvaranja anaforičkoga niza uputa koje prethode završnoj opomeni.

Pseudo-Bernardov tekst o strahu Božjem i ljubavi pretvoren je ovdje $\mathrm{u}$ upućivanje $\mathrm{u}$ ispravan život $\mathrm{u}$ kojem istaknuto mjesto pripada mudrosti, te nećemo pogriješiti ako iznesene sentencije shvatimo kao pojednostavnjene i široj publici prilagođene upute u modo bene vivendi.

Usporedba Kapitula sa starijim paralelnim tekstom iz Petrisova zbornika, kao i usporedba Petrisova zbornika s lat. traktatom, upozorila je i na neke sličnosti između staroga i novoga sloja kompiliranja. Riječ je o uporabi sintaktičkog paralelizma kao kompilacijske spojnice kojom se vješto prikrivaju mjesta spajanja dvaju različitih tekstova.

Ovim se radom povećao broj poznatih prijepisa starijeg hrvatskog prijevoda Pseudo-Bernardova traktata. Osim toga na temelju dvaju novih identificiranih tekstova broj se podudarnih tekstova između Petrisova i Grškovićeva zbornika popeo na njih čak 13, što svakako nije zanemarivo. 


\section{TEKST}

U ovom se radu prvi put objavljuju Kapitul iz Grškovićeva zbornika, S(lovo) s(ve)t(a)go Brnarda ot straha i kratka zbirka moralnih izreka iz Petrisova zbornika. Tekstovi se objavljuju u stupcima kako bi se olakšalo praćenje paralelnih mjesta. Bilješkama u lijevom stupcu označuju se počeci odlomaka lat. traktata. U transliteraciji je za slovo đerv uzeto $\hat{\jmath}$, za jus $\hat{u}$, za jat ê, za poluglas ь i apostrof '. Kraćene riječi razriješene su u okruglim zagradama. Početak folija naveden je unutar teksta kosim crtama.

Počine vele lip kapitul i koristan, CGrš, 185r-189r

$\mathrm{O}^{30}$ bratiê draga, slišite ča vam' govorim', i zato vas' spominam' razumiite ča vam pravlu. Boga se vazda boêti imamo zvrhu vsega i zapovedi nega obslužiti, /185v/ zač su oči gospodni zvrhu onih' ki se nega boe i na onih' ki ufaû v nega milosrdie.

Ot toga Solomun govori: boi se B(og)a i otluči se ot zla zač' on' ki se B(og)a boi vsako dobro čini. I oĉe Solomun piše: strah B(o)ži, slava i proslavlenie gospodne $\mathrm{i}$ koruna vesela. Strah' gospod(a)n' veseli srce i dae veselie i radost' v dlgotu dni, zač' ki e bes straha ne bude pravdan'. Strah' gospodan est mudrost' i nauk'. Ne budi neveran' v strahu g(ospo)dni i ne idi k nemu z dvoim' srcem'.
S(lovo) s(veta) go Brnarda ot straha $k(a) p(i) t(u l) g(=4)$, CPet, $4 \mathrm{v}-7 \mathrm{r}$

Moê draga brat'ê, slišite ča vam' govorim' i zato vas' vspominam' da bi razumeli ča vam' pravim'. $\mathrm{B}(\mathrm{og})$ a toga se vazda boimo zvrhu vsega zač' oči g(ospod)ni esu na onih' ki se nega boe i na onih' ki ufaû na nega m(i)l(o)srdie.

Oh(rbst) tada zapovedi ego obslužemo i od togo Solomun govori: boi se $\mathrm{B}(\mathrm{og})$ a i otluči se ot zla. Zač' on' ki se B(og)a boi vsako dobro čini. I oĉe Solomun govori strah B(o)ži sl(a)va i proslavlenie i veselie i koruna vesela. Strah' g(ospoda)n' veseli srce i vzdae veselie i radost' v dlgotu dni, zač' bez straha nigdore ne budê pravdan. Strah' g(ospoda)n' es(t) mudrost' i nauk'. Ne budi neveran' $\mathrm{v}$ strahu g(ospod)ni i ne hodi $\mathrm{k}$ nemu v dvoenii srca.

30 Početak odlomka 7. poglavlja De timore Dei. PL 184, 1203 C. 
$\mathrm{Ki}$ se $\mathrm{B}(\mathrm{og})$ a boite strpite nega milosrdie i ne dilite se ot nega da se ne padete.

$\mathrm{Ki}$ se $\mathrm{B}(\mathrm{og})$ a boite veruite $\mathrm{v}$ nega $\mathrm{i}$ dobro tvorite da ne bude taĉa vaša plaĉa, da pride k vam' milosrdie Božie.

Ki se boite $\mathrm{g}$ (ospod)a lûbite nega $\mathrm{i}$ prosvatet se srca vaša.

$\mathrm{Ki}$ se $\mathrm{B}(\mathrm{og}) \mathrm{a}$ boe nisu neverni zapovedi nega i ki lûbet' $\mathrm{g}($ ospo)dina $\mathrm{B}(\mathrm{o}) \mathrm{ga}$ ti hodet' putem nega.

Ki se B(og)a boe ti iĉu ka su ugodna nemu i ki nega lube plni su zakona nega.

Ki se $\mathrm{B}(\mathrm{og})$ a boe ti pripravie srce svoe da se pred licem' Božim' prosvete duše nih.

Ki se B(og)a boi ta obsluži zapovedi nega.

Oči g(ospo)dni zvrhu onih ki se nega boe i on zna dela nih'.

Svršenie straha Božiê est mudros't.

Ki se $\mathrm{B}(\mathrm{og})$ a boi ta zla ne naide $\mathrm{i}$ /186r/ napasti se izbavla.

Strah' Boži e(st) kako rai, vsaka slava pokriet ego. B(la)žen muž e(st) komu e dano boêti se B(og)a.

Strah g(ospo)dan' est početak' nega lubve.
Ki se $\mathrm{B}(\mathrm{og}) \mathrm{a}$ boite strpite nega m(i)l(o)srdie i ne dilite se ot' nego.

Ki se $\mathrm{B}(\mathrm{og})$ a boite vêruite $\mathrm{v}$ nega $\mathrm{i}$ dobro tvorite da ne bude taĉa vaša plaĉa, /5r/ da pride k vam milosrdie B(o)žie.

Ki se boite g(ospod)a lûbite ga da se prosvêtê srca vaša.

$\mathrm{Ki}$ se $\mathrm{B}(\mathrm{og}) \mathrm{a}$ boe nisu neverni zapovedi nega i ki lûbe $\mathrm{B}(\mathrm{og}) \mathrm{a}$ ti hodet putem' ego.

Ki se B(og)a boe ti iĉu ka su emu ugodna i ki nega lûbe plni su nega zakona.

$\mathrm{Ki}$ se $\mathrm{B}(\mathrm{og})$ a boe ti priprave srce svoe da se pred licem' B(o)žiim' prosvêtlê d(u)še ih'.

Ki se $\mathrm{B}(\mathrm{og})$ a boi ta obslužue zapovedi ego i trpi (p)okornos'ti.

Oči esu zvrhu onih' ki se B(og)a boe, on' zna nih' vsa dela.

Svršen'e straha Božiê es(t) mudrost'.

Ki se B(og)a boi ta zla ne naide $\mathrm{i}$ napasti se izbavla.

Strah B(o)ži es(t) kako rai, zač' vsaka sl(a)va pokriet' ego.

$\mathrm{B}(\mathrm{la}) \mathrm{z}(\mathrm{e}) n^{\prime}$ muž es(t) komu dano es(t) boêti se B(og)a.

Strah' g(ospoda)n' es(t) početak' nega lûbve. 
O bratiê draga, ${ }^{31}$ niedna rič' ni čini nas čistih' ot griha kako strah' Boži i lubav Božiê.

Boga se e(st) boêti, niedno zlo ne činiti.

Strah Boži est istočnik' mudrosti.

Ki se B(og)a boi dobro bude imel na konci v životi i v semrti svoei bude blažen'.

Bratiê, dobro est nam' B(og)a boêti se ere strah' gospod(a)n otgana grih', strah' Boži čini mudra čl(ovê)ka i na dobro vazda želi.

Da kadi straha ni ondi e pogibel' duši, kadi ni straha tu e rasprostranstvo života i ondi e obilie griha. I zato, draga bratiê, strah' i ufanie budi vazda $v$ srci vašem' na kup', budi v tebi strah' i ufanie. I tako e drži milosrdie vazda se boi nega pravde.

Bratiê draga, ${ }^{32}$ v Krsti Isusi esu četiri strasi. Prvi est plteni, a to est kada se boimo pogibeli ili inoga zla ali zgubiti niko blago i zlo pregrišuemo. A ta grih est vele zal'. I zato ga vzbranue gospodin' v' evaneli govorecii: ne boite se onih' ki ubiêût telo.
O bratiê draga, niedna rič' nas' ne čini čis'tih' ot greha kako strah' i lûbav' B(o)žiê.

$\mathrm{B}(\mathrm{og})$ a se e boêti, ne činiti niednoga zla.

Strah' g(ospoda)n' es(t) istočnik' mudros'ti.

Ki se B(og)a boi dobro bude imel' na konci v životi i v semrti svoei bude bl(agoslovle)n'.

O bratiê, dobro es(t) nam' B(og)a boêti se, zač' strah' B(o)ži odgana grih', strah' B(o)ži čini mudra č(lovê)ka i na dobro vazda želi.

Da kadi straha ni on'di e pogibel' d(u)ši, kadi ni straha tu e rasprostranstvo života, kadi ni straha ondi e obilie griha. I zato draga brat'ê strah' i ufanie vazda budi v srci vašem', na kup budi v tebê strah' i ufanie. I takoe se drži $\mathrm{B}(\mathrm{o})$ žiê m(i)losrdiê i vazda se boi nega pravde. $/ 5 \mathrm{v} /$

O moê draga bratê, va Is(u)h(rbst)i esu četiri strahi. A to es(t) prvo plteni kada se boi pogibêli ali inoga zla, ali zgubiti niko blago za ko i zlo pregrešuemo. Zač' ta isti grih es(t) zal i zato ga vzbranue g(ospo)d(i)n' v e(van)ĵ(e)lii govoreĉi: ne boite se onih' ki ubiêût' telo.

\footnotetext{
31 Početak odlomka 8. poglavlja De timore Dei. PL 184, 1204B.

32 Početak odlomka 9. poglavlja De timore Dei. PL 184, 1204C.
} 
Drugi strah' est službeni a to e kada se človik boi muke paklene, a ne za lubav' Božiû ter niko dobro čini on' kako rab' boit se i ot' zla čuva se. /186v/ I o toga s(ve)ti Pav(a)l' piše: niste prieli duha rabote i opet v strahu priêli ste duh sini Božih.

Ta strah e dob(a)r ako i ni zadovolan na spasenie i svršen po kom' v nas' raste malo dobra činenê. Kada človik počne verovati dan sudni počne se ga boêti, da ki ga se boi ta nima svršena ufanê na dan' sudni, ere v takovi ni svršena lûbav' ne bi se boêl.

Svršena lûbav' čini svršena čl(ovê)ka va vsem' dobri i zato ne imel bi se boêti da želiti cesarastva nebeskoga zač e svršena lûbav' bola nere svršena svetina.

Oni imaû v sebi svršenu lûbav' ki pravo živut' i zato nima se boêti on' ki pravo živet' i nima se boêti paklene uze nere ima želiti ukrašeniê nebeskoga.

I zato piše prorok': proslavet' se o tebi vsi ki lûbe spasenie i ${ }^{33}$ zato piše Solomun v kantiki moĉan' est
Drugi strah' es(t) službeni, a to es(t) kada se č(lovê)k boi muke paklene, a ne za lûbav' B(o)žiû tre niko dobro čini. I ta kako rab' boit' se i ot zla čuva se. I ot toga s(ve)ti Paval' piše reki ne priêste bo d(u)ha rabote i vaspet' di ap(usto)l' Paval' o strahu priêste d(u)h' sini B(o)žih'.

I ta strah' es(t) dobar ako si i ni zadovolan na sp(a)senie i svršen' po kom' v nas' raste malo dobra činen'ê kada č(lovê)k počne verovati dan' sudni počne se ga boêti. Da ki se ga boi ta nima svršena ufan'ê na dan' sudni, zač' v takovi ni svršena lûbav' ki se semrti boi. Zač' ako bi v nem' svršena lûbav' ne bi se boêl'.

Svršena lûbav' čini svršena č(lovê)ka va vsakom' dobri. I zato bi se ne imel boêti na želeti c(êsa)rstva n(e)b(e)skago. Zač' svršena lûbav' bolša es(t) nere svetina svršena.

Oni imaû svršenu lûbav' ki pravo živut' i zato nimaû se boêti zač' pravo i svršeno živut'. Zato se nimaû boêti paklene muke na imaû želeti n(e)b(e)skoga ukrašeniê.

I zato govori prorok': proslavet' se

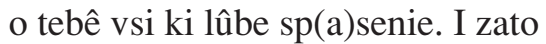
piše Solomun' v kan'tiki moćna

33 Početak druge polovice odlomka 12. poglavlja De charitate, PL 184, 1207A. Nisu prevedeni odlomci 10. i 11. poglavlja De timore Dei u kojima se tumače dvije vrste straha (initialis timor i castum timor) ni veći dio odlomka 12. poglavlja De charitate. 
kako i semrt' ka silu razdili dušu ot teloa i tako lubav' Božiê oddili č(lovê)ka ot riči pltenih' i sega svitnih'.

Istina e lubav' Božiê i est kako semrt' zač' kada se za lûbav' Božiû ot' griha čuvamo, ča semrt učini v znameni telesnom' to učini lûbav' Božiê vsega svatnem poželenjî /187r/ Lûbav' est B(og). Lûbavlû se lûbi sam $\mathrm{B}(\mathrm{og}) \mathrm{v}$ sebi, a iskrnni za lûbav Božiû, a to e da ima $\mathrm{B}(\mathrm{og})$ lûblen biti veĉe vsega svita riči, a iskrni va vsako dobro.

Lûbav ${ }^{34}$ ima dvi zapovedi. Prva est $\mathrm{B}(\mathrm{og})$ a lûbiti ka e prava istinna, a drugo est' lûbiti iskrnega kako sam' sebe, a to e da imaš' lûbiti iskrnega. Nato nač' imaš' ti sebe lûbiti da bude lûbav' svršena, a to est lûbi ga na dobro da bude svršen' ere ako lûbiš' iskrnega na zlo ne lûbiš ga da nenavidiš ga. A ki ne vidi i ne zna iskrnega tr ga lûbi pravu lûbav' svršue da ne lûbi iskrnega koga vidi kako on oĉe $\mathrm{B}(\mathrm{og})$ a lûbiti koga ne vidi kako ga more lûbiti. On' ki lûbi iskrnega svoga svoga B(og)a vidi i od Boga se e rodil'. Ki lûbi iskrnega koga vidi učima telesnima, vidi i lûbi $\mathrm{B}(\mathrm{og}) \mathrm{a}$ i B(og) lûbav est.

I oĉe imamo lûbiti bližike naše ako su dobri i ako B(og)u služe i veĉe imamo lûbiti strannoga ki e svezan' es(t) lûbav /6r/ kako i semrt ka silu

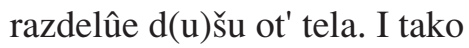
lûbav B(o)žiê otluči č(lovê)ka ot rêči pltaiskih' i svet'skih'.

Istin'na lûbav' B(o)žiê es(t) kako i semrt', zač' kada se za lûbav' $\mathrm{B}(\mathrm{o})$ žiû ot greha čuvamo ča čini semrt' v znameni' telesnom', to čini lûbav B(o)žiê v želen'i sega s(ve)ta. Lûbav' B(og) es(t). Ku lûbav'û lûbi se sam' B(og)b v sebê, a iskrni za lûbav' $\mathrm{B}(\mathrm{o})$ žiû. A to es(t) da ima $\mathrm{B}(\mathrm{og}) \mathrm{b}$ lûblen' biti više i veĉe ot vseh riči sega sveta, a iskrni va vsakom' dobri.

Lûbav' ima dvi zapovêdi. Edna e(st) B(og)a lûbiti ka e prava istin'na, a druga e(st) lûbiti iskrnega kako samoga sebê. A to es(t) da imat' iskrnega lûbiti. Na to nač' ti imaš' sam' sebê lûbiti da bude lûbav' svršena, a to es(t) lûbiti ga na dobro da bude svršen'. Zač' ako lûbišs' iskrnega na zlo ne lûbi ga da nenavidi ga. A ki ne lûbi iskrnega koga vidi, $\mathrm{B}(\mathrm{og})$ a koga ne vidi kako more lûbiti. On' ki lûbi iskrnega svoego $\mathrm{B}(\mathrm{og})$ a vidi i ot Boga se e rodil'. Ki lûbi iskrnega koga vidi očima teles'nima vidi i lûbi B(og)a zač' B(og)b lûbav' es(t).

Oĉe imamo lûbiti i bližiki n(a)še ako su dobri i ako B(og)u služe. I veĉe imamo lûbiti stran'nago ki e s

34 Početak odlomka 13. poglavlja De charitate. PL 184, 1207B. 
s nami lûbvu duhovnu nere naših' bližik' ki ne lûbe $\mathrm{B}(\mathrm{og})$ a ni mu služe ere e veĉe sveto edinstvo duhovno nere telesno i vsih' vernih' krstên' mi imamo lûbiti onih' prvo ki su s nami stisnuti lûbavl'û duhovnu imamo nih lûbiti i pomoĉi a inih koliko naiveće moremo.

Bratiê $\hat{e}^{35}$ moê $/ 187 \mathrm{v} /$ draga, ako istinnu lûbav budemo održati vsa blaga imiti budemo. I oĉe imamo lubiti nepriêtele naše kako govori v svetom evaneliû: lûbite nepriêteli vaše i dobro činite onim' ki vas' nenavide i molite za onih' ki vas' progone da budete sinove oca vašega ki e(st) na nebesih'. I zato nam' e(st) potribno lûbav' imiti ere bez ne niedan ugoditi $\mathrm{B}(\mathrm{og}) \mathrm{u}$ ne more. On' ki nenavidi iskrnega ta i Boga ne lûbi, on' ki svršue nega zapovedi ta lûbi $\mathrm{B}(\mathrm{og})$ a ere lûbav' est koren' vsih' dobrot' zač' prez lûbve ča koli činimo ništar nam prudno ni, kadi e(st) $\mathrm{B}(\mathrm{og})$ ondi gospodue velika i neizmerna lûbav, zato e(st) čl(ovê)k potriban' i dob(a)r' ki e pln' lûbve i ki koli verue $\mathrm{k}$ božastvu nigdar' priti ne more na mane. Tolika dobrota est lûbve da bez ne vse kriposti nisu ništar vridne da lûbav' imiûce vse su vridne i korisne. Ki ne lûbi $\mathrm{B}(\mathrm{og}) \mathrm{a}$ ta sebe nenavidi. nami svezan' lûbav'û d(u)hov'nu nego n(a)še bližike ki ne lûbe B(og)a ni mu služe. Zač' e veĉe sveto edins'tvo d(u)hovno nego teles'no i vse verne krst'êne /6v/ imamo lûbiti. Da onih' naipriê ki su s nami stisnuti lûbavl'û d(u)hovnu imamo nih' lûbiti i pomoĉi, a inih koliko naiveće moremo.

Bratiê moê draga, ako istinnu lûbav' udržati budemo to večni život udržati budemo. I oĉe imamo lûbiti i nepriêteli n(a)še kako govori v svetom' evanĵ(e)li: lûbite nepriêteli v(a)še i dobro tvorite onem' ki vas' nenavide i progone da budete sinove o(t)ca $v(a)$ šego ki es(t) na nebesih. I zato nam' potrebno lûbav' imeti zač' bež n'e niedan' ni drag' B(og)u. On' bo ne lûbi inogo ki iskrnega nenavidi. $\mathrm{Ni}$ $\mathrm{B}(\mathrm{og}) \mathrm{a}$ on' lûbi ki ako si i zapovedi ego svrši zač' lûbav' koren' es(t) vsih' dobrot'. Zač' bez lûbve ča koli činimo niĉe nam ni prudno. On'di kadi es(t) B(og)ь ondi gospodue velika velmi hoteniê lûb've. Zato es(t) č(lovê)kb potriban' i dobar ki es(t) pln' lûb've i ki verue $\mathrm{k}$ božastvo nigdare ne more priti na mane. Tolika e dobrota lûbve da bez' ne vse ine kreposti nisu niĉe vredne ni stanovite da lûbav imeûce vridne i stanovite. Ki $\mathrm{B}(\mathrm{og}) \mathrm{a}$ ne lûbi ta sebê se lûbi.

35 Početak odlomka 14. poglavlja De charitate. PL 184, 1208B. 
Sada vas svetuû, draga bratiê da se lubvu svežete sa onim koga nenavidite i da greš želiûci Is(u)h(rbst)a niedne riči sega s(ve)ta više nega i imaš svoi život' za ništar držati da ne primiš veselê sega svita.

I oĉe telesno zdravie za ništar' cini za lûbav' Božiû ranom' /188r/ ot lûbve Božie budi tvoe srce probodeno tako da istinno moreš' reĉi ranen esam'.

Slišite ča sam Is(u)h(rbst) reče ki lûbi mane lûblen' budet' ocem' moim i ê budu nega lûbiti i êvim se emu sam'. Tada bratiê lûbimo B(og)a v sem životi da nas' pomilûe otac' nebeski v cesarastvom' nebeskom'. ${ }^{36}$

Slišite ${ }^{37}$ ča s(ve)ti Paval govori ot lûbve bole biti ne more ere lûbav' est mirotvorna trpeliva to est ne vzdati zlo za dobro blagoditna est lûbav' i ne podobaet nam prêti se nad krotkim i trplivim' biti vsagda to e ne lûbiti suetnih' vika sego ni gizde ni pohoti tela ni nenavisti ni protivĉin meû bratiû.
A sada vas' svetuû draga moê bratê da se svežite sa onim koga ne vidite vzlûblenoga vaše d(u)še obručenika Is(u)h(rbst)a i da gredête za nim' želeûci ga veĉe i više nere niedne riči sega sveta. Imate svoi život' za niš 'tarê držati i da se ne veselite va vesel'i sega sveta.

I oĉe $/ 7 \mathrm{r} /$ da se ne veselite va vesel'i sega sveta. I da telesno zdravie za ništar cenite skozê B(o)žiû lûbav'. Ranoû B(o)žie lûbve srce vazda budi raneno i probodeno. Tako da istin'no morete reĉi ranen' esam'.

Slišite ča Is(u)h(rbst) r(e)če: ki mene bude lûbil bude vzlûblen ot oca moego. I ê nega vzlûbim' i êvlû se nemu sam'. A tada draga moê bratê, lûbimo B(og)a v tom' životê da nas' polûbi $\mathrm{B}(\mathrm{og}) \mathrm{b}$ ot(a)c sa sinom' v c(êsa)rstvê n(e)b(e)skom. Amen'

\footnotetext{
36 Završetak 14. odlomka poglavlja De charitate. PL 1208D.

37 Početak Pavlovih poslanica.
} 
CPet, /238r-239r/

$\mathrm{Ako}^{38}$ mudar' budeši to sebi iskarnim, ako li manen' to sam sebi.

Sin' mudar' veselit' oca, a sin' manen' pečal' materi svoei.

I dast' se dobrim eesarastvo bogataistvo, a ot' zalih' otemlet' se.

Bole e(st) ime dobro, nego masti prekrasnie i dan' semrti nere roistvo.

Milûe niĉa v zaêm daet gospodeve i podaniû ego vzdast se emu.

Šestera sut ka nenavidit gospodin i sedmero svedokuet duša ego: oči visokie, êzik lažliv, ruke prolivaûce krv nevinnu, i srce va obražuûce, misli lûtie, nogi tekuĉe na zlo, govoreĉih laž, svedoka kriva /188v/. I togo ki sie meû bratiû nenavist'.

Ako ča obeĉal' esi g(ospod)u vzdai, ne kasni i neugodan' est nemu neverni i bezumno obeĉanie mrzit' nemu načto obeĉaš i vzdaš. Mnogo bole est ne obeĉavaši dati neže obeĉavaši tr ne dati.

Ne dai ust tvoih da ne svedet' plt' tvoû eda kako prognivaet se na te
Ako mudar budeš' to sebi i iskrnemu, ako li nor' to sebe.

Sin' mudar veseli o(t)ca, a sin nor' pečali mat(e)r svoû.

Dast' se pravim' bogatastvo, a zalim' otemlet' se.

Bole es(t) ime dobro, nego masti mnogocen'nie i dan' smrti nerê roistva.

Miluet niĉa v zaêm' daet' g(ospode)ve i podaêniû ego dast se emu.

Šestera sut ka nenavidi g(ospodin)ь i sedmo svedokuet d(u)ša ego: oči visoce, ezik laživ', ruke prolivaûce krv nevin'nu i srce va obražuûce misli lûtie, nogi tekuĉee na zlo, svedoka kriva gl(ago)û̂̂(a)go /238v/ lažu i togo ki čini mêû brat'û svadu.

Ako pravadni edva sp(a)set se, a grešnik' kadê êvit' se.

Ako ča obeĉal esi g(ospod)u vzdai ne kasni. Neugodan bo emu es(t) nevêrni i bezumno obeĉanie da čto obeĉaši vzdai. Mnogo bole es(t) ne obeĉavši dati nerê po obeĉaniû obeta ne vzdati.

Ne dai ust' tvoih' da ne svêdêt plt tvoû ne r(e)ci pred anĵ(e)lom nest'

38 Početak kratke zbirke sentencija. 
$\mathrm{B}(\mathrm{og})$ i ne pogubi vsa dela ruk tvoih.

Srce mudrih' kadi skrb' ih' est', srce že norih' kadi est veselie.

Žena dobra vinac' muža svoego est a žena huda pogiblaet' hišu muža svoego.

Boli e ubog' veran', nere bogat' lažliv'.

Mudri sveta poslušaet, nori ga otmetaet'.

Manen čl(ovê)k' naglo pustit' gniv, mudar že rasmotriv.

Pokarai mudra, vzlubit te, a nori vznenavidit te, dai mudru krivinu i mudri budet, skaži nemu pravdu i vzlubit te.

Začelo premudrosti strah' gospodan.

V tom' budi skor slišati, a kasan' otgovoriti.

Trpeliv' v gnivi. Kada ča počneš' učinie mudro i vazda razmisli konac.'

Nigdar se onim' ne diči čim se oĉeš' sramovati.

Ki se va te poufa, kako sam' sebe shrani. prosmotreniê eda kako prognevaet se na te $\mathrm{B}(\mathrm{og})$ b i pogubi vsa dêla ruk' tvoih'.

Srce mudrih' kadê skrb' es(t), srce že norih' kade es(t) veselie. Žena dobra venac' mužu, a žena zla kako črv' drevo gubit' muža.

Boli e ubog veran' nere bogat laživ.

Mudar sveta poslušaet nori ga otmetaet.

Nori že v nagle ispustit' gnev', mudar že smotrit'.

Pokarai nora da te vznenavidit' a pokarai mudra i vzlûbit' te. Dai mudru krivinû i mudrêi budêt' i skaži emu prava i vzlûbit tê.

A poiti e d(u)ši na pakal' tužno tre nevolno svoe grehi na sebi žalostno nesuĉi.

Začelo mudrosti es(t) strah g(ospoda)nь.

$\mathrm{V}$ tom budi skor slišati, kasan govoriti

Trpeliv' v gnevê. A kada ča hoĉ' učiniti učini e mudro i vazda misli niki konac hoĉe tvoe činenie priti.

(C) A nigdar se onim' ne diči čim se hoĉ' sramovati.

A taĉinu se ne hvali.

A ki se va te poufa kako sam' sebê shrani. 
Zač' č(lovê)ka va zlo vnašaû bêsedê. Zato vas' vsaki vari sebê.

Ne dai po voli misli svoei.

(C) Ne dai povolstva misli tvoei da ne budê zla d(u)ši tvoei.

Ne imii družbi sa ženu lûkavu da ne izgoriš' ognem' ee. /189r/

Ne imêi družbê s ženu lukavu da ne izgoriš' ognem' ee.

Ne imi družbi s mladim ditiĉem' da Ne imêi družbi s malim dêtêtem' ne vpadeš' vset' ob nem'. da ne vpadêš /239r/ vset' i š nim.

$\mathrm{Ne}$ imii družbi sa starišinu mesta na poslišai riči nega.

Ne imei družbi s starêši mes'ta da poslušai s(love)s ego da po dêlêh' ne tvori.

Ne hodi po gradu fraêe ili migae da ne budeš' posmiên'.

Ne idi po gradu ali po seli fraêe ali migae da ne budêši posmeên'.

Ne pit vina mnogo da te ne povrati $\mathrm{v}$ norost'.

Ne pii vina mnogo da tê ne povrati v norost.

Ne iĵi vele krat' va dne da v beteg' Ne ĵii vele krat' va dne da vpadêš $v$ ne vpadeš'. bêteg'.

Ne zatavarai dvari tvoih' pred' Ne zatvori dvari tvoih' pred ubogim' da gospodin' B(og) tebi ne zatvori vrat raiskih'. ubogimi da ne zatvori В(og)ь dvari svoih' pred tobu.

I kako budeš miril tako e i tebi Ku meru budeš' meriti tako se tebi mirilo bude. budê meriti.

(C) Ne budi sinu opiêvac' ni lûbodêinik' da ne obniĉaš' zač' ki obniĉa v poruganii budê. 


\section{IZVORI}

CGrš - Grškovićev zbornik, 16. st., Arhiv HAZU, sign. VII 32

CPet - Petrisov zbornik, 1468., NSK, sign. 4001

PL 184 - Bernardus Claraevallensis: Liber de modo bene vivendi ad sororem, PL, knj. 184, (ur. J.-P. Migne), 1859, Paris, 1199-1306D.

\section{LITERATURA}

Badalić, Josip. 1952. Inkunabule u Narodnoj Republici Hrvatskoj, Djela JAZU, knj. 45. Zagreb: JAZU.

Badurina Stipčević, Vesna. 2015. Priča o premudrom Akiru u hrvatskoglagoljskom Petrisovu zborniku (1468), u: Hrvatsko glagoljaštvo u europskom okružju, ur. V. Badurina Stipčević, S. Požar, F. Velčić. Zagreb: Staroslavenski institut, 379-398.

Badurina Stipčević, Vesna (prir.). 2013. Hrvatska srednjovjekovna proza. Knj. 1, Legende i romani. Zagreb: Matica hrvatska.

Béné, Charles. 1998. L'Institutio de Marulić Revisitée. Essai sur les raisond d'un succès. "Colloquia Maruliana", VII, 145-176.

Bloomfield, Morton Wilfred. 1979. Incipits of Latin Works on the Virtues and Vices, 1100-1500 A. D.: Including a section of incipits of works on the Pater noster. Cambridge: Publications of the Mediaeval Academy of America.

Bremond, Claude, Jacques Le Goff, Jean-Claude Schmitt. 1996. L' “Exemplum”, Typologie des Sources du Moyen Âge occidental, fasc. 40. Turnhout: Brepols.

Delcorno, Carlo. 2000. Medieval preaching in Italy (1200-1500). The Sermon, Typologie des Sources du Moyen Âge occidental, fasc. 81-83, ur. B. M. Kienzle. Turnhout: Brepols, 449-560.

Dürrigl, Marija-Ana. 2010. O čitanju, pisanju i kompiliranju u hrvatskoglagoljskom srednjovjekovlju, "Slovo", 60, 219-234.

Dürrigl, Marija-Ana. 2007. Čti razumno i lipo. Ogledi o hrvatskoj srednjovjekovnoj književnosti. Zagreb: Hrvatska sveučilišna naklada.

Fališevac, Dunja. 2007. Stari pisci hrvatski i njihove poetike. Zagreb: Hrvatska sveučilišna naklada.

Fališevac, Dunja. 1980. Hrvatska srednjovjekovna proza. Književnopovijesne i poetičke osobine. Zagreb: Sveučilišna naklada Liber.

Glavičić, Branimir. 2010. Predgovor: Marko Marulić - europski humanist, u: Marko Marulić: Upućivanje u čestit život po primjerima svetaca, preveo, komentirao i priredio Branimir Glavičić. Zagreb: Nakladni zavod Globus, XI-XXI.

Gunn, Cate. 2008. Ancrene Wisse: From Pastoral Literature to Vernacular Spirituality. Cardiff: University of Wales Press.

Hercigonja, Eduard. 1983. Nad iskonom hrvatske knjige. Zagreb: Sveučilišna naklada Liber. 
Hericgonja, Eduard. 1975. Povijest hrvatske književnosti: srednjovjekovna književnost, knj. 2. Zagreb: Liber-Mladost.

Kolumbić, Nikica. (prir.) 1990. Petar Lucić: Vartal. Split: Književni krug.

Kuczynski, Michael P. 1995. Prophetic Song: The Psalms as Moral Discours in Late Medieval England. Philadelphia: University of Pennsylvania Press.

Kukuljević, Ivan. 1869. Marko Marulić i njegovo doba, u: Marko Marulić: pjesme Marka Marulića, Stari pisci hrvatski, knj. 1. Zagreb: JAZU, I-LXXVII.

Maixner, Franjo. 1885. Prievodi t. z. "Disiticha moralia Catonis" u hrvatskoj literaturi. RAD JAZU LXXIV, 79-134.

Mouron, Anne. 2014. The Manere of Good Lyvyng. A Middle English Translation of Pseudo-Bernard's Liber de modo bene vivendi ad sororem. Turnhout: Brepols.

Mouron, Anne. 2012. Praying without images, "The Way", 51/4, 91-101.

Mouron, Anne. 2000. Listen to me, daughter, listen to a faithful counsel: The Liber de modo bene vivendi ad sororem, $\mathrm{u}$ : Writing religious women. Female Spiritual and Textual Practice in Late Medieval England, ur. D. Renevey; C. Whitehead. Toronto: University of Toronto Press.

Newman, Barbara. 2012. Liminalities. Literate Women in the Long Twelfth Century, u: European Tranformations. The Long Twelfth Century, ur. T. F. X. Noble, J. van Engen. Notre Dame, Indiana: University of Notre Dame Press, 354-402.

Newman, Barbara. 1989. Flaws in the Golden Bowl. Gender and spiritual formation in the Twelfth century, "Traditio", 45, 111-146.

Ogilvie-Thomson, Sarah J. 2000. The Index of Middle English Prose, Handlist XVI: Manuscripts in the Laudian Collection, Bodleian Library, Oxford. Cambridge: Brewer.

Pandžić, Zvonko. 2009. Nepoznata proza Marka Marulića. O novootkrivenim $i$ novoatribuiranim hrvatskim rukopisima. Zagreb: Tusculanae editiones.

Pinder, Janice. 2001. The Cloister and the Garden: Gendered Images of Religious Life from the Twelfth and Thirteenth Centruies, u: Listen, Daughter. The Speculum Virginum and the Formation of Religius Women in the Middle Ages, ur. C. J. Mews. New York: Palgrave, 159-179.

Reinhart, Johannes. 2012. Nauk sinu Vičerdovu u hrvatskoglagoljskoj književnosti, "Slovo", 62, 211-232.

Reinhart, Johannes. 2010. Kombinacija dvaju mirakula u hrvatskoglagoljskom rukopisu (Grškovićev zbornik, HAZU VII 32), "Slovo", 60, 669-686.

Rice, Nicole. 2008. Lay piety and religious discipline in middle English literature. Cambridge: Cambridge University Press.

Sambunjak, Slavomir. 1997. Bernardinski tekstovi hrvatskoga srednjovjekovlja, Radovi Filozofskog fakulteta u Zadru, 36 (26), 1-24.

Sharpe, Richard. 1997. A Handlist of the Latin Writers of Great Britain and Ireland before 1540. Turnhout: Brepols.

Štefanić, Vjekoslav. 1970. Glagoljski rukopisi Jugoslavenske akademije, II dio. Zagreb: JAZU.

Štefanić, Vjekoslav. 1960. Glagoljski rukopisi otoka Krka, Djela JAZU, knj. 51. Zagreb: JAZU. 
Zlatar, Andrea. 2001. Transformacije hagiografske matrice u Marulićevu djelu De institutione bene beateque vivendi per exempla sanctorum, "Colloquia Maruliana", $10,77-85$.

\section{SUMMARY}

\section{VELE LIP KAPITUL I KORISTAN - LIBER DE MODO BENE VIVENDI AD SOROREM IN GRŠKOVIĆ'S MISCELLANY FROM THE $16^{\text {th }}$ CENTURY}

Manuscripts written in Glagolitic script contain transcriptions of older compilations as well as texts which consist of fragments of older works - presumably compiled by the scribe. Vele lip kaptiul i koristan, a didactic text from the Gršković's Miscellany which up to this point hasn't attracted attention, belongs to the latter group of texts preserved in the manuscripts. Kapitul is composed of two medieval texts that were already known in Croatia in the $15^{\text {th }}$ century: 1 ) an older Croatian translation of the chapters De timore Dei and De charitate from the Pseudo-Bernard's Latin work Liber de modo bene vivendi ad sororem and 2) a short list of maxims. The research has shown that the list of maxims that was added to the translation of the Latin treatise intensified the moral lesson of the text, whereas the text itself acquired generic qualities of a sermon. Apart from its other known Glagolitic and Latin transcription, the text Vele lip kaptiul $i$ koristan is another confirmation of the popularity and presence of this Latin treatise in the Croatian literature.

Keywords: vernacular literature, compilation, Gršković's Miscellany, Liber de modo bene vivendi ad sororem 